\title{
Ethno - medicinal plants for skin diseases and wounds from Dapoli Tehsil of Ratnagiri District, Maharashtra (India)
}

\section{R. L. Ghalme}

\author{
Department of Botany, \\ Dapoli Urban Bank Senior Science College \\ DAPOLI, Dist. RATNAGIRI (M.S.), INDIA. \\ Email: rlghalme@gmail.com
}

Received : 25.02.2020; Revised : 30.04.2020; Accepted : 02.05.2020

\begin{abstract}
Ethno-medicinal plant surveys were conducted in Dapoli Tahsil for documentation of traditional knowledge of Tribes and villagers. The present paper deals with ethno-medicinal plants used for control of skin diseases, burns, cuts and wounds. Total 65 plant species belong to 62 genera of 39 families are used in different forms to control the skin diseases, burns, cuts and wounds. Out of total 65 species, 1 species belongs to Pteridophytes, 64 species belong to 61 genera of 38 different families of Angiosperms. Out of 64 species of Angiosperms, 62 species belong to 59 genera of 36 families of Dicotyledons while 2 species belong to 2 genera of 2 families of Monocotyledons. Fabaceae is the dominant family with 5 species used followed by Combretaceae with 4 species and Lamiaceae, Asteraceae, Apocynaceae and Acanthaceae families with 3 species each are reported.

KEY WORDS : Ethno-medicinal, Skin diseases, Tribes, Wounds.
\end{abstract}

\section{Introduction}

Rural and Tribal people are using various plants as a source of medicines as they are living far away from recent medical facilities. The topographic, edaphic and climatic conditions of Dapoli favors for the growth and formation of thick vegetations. The climatic conditions also favors the growth of microorganisms on skin of human being as well as on the clothes, shoes, etc. This leads in formation of different skin diseases not only in human being but also in different animals in rural areas. To treat such ailments villagers and tribals have developed knowledge by using surrounding plants by experience and practice passed from generation to generation. For the documentation of such valuable traditional knowledge the present work was undertaken.

Dapoli Tahsil is totally hilly area, situated along the coast of Arabian Sea. It lies between $17^{\circ} 4-54^{\prime \prime}$ North latitude and $73^{\circ} 10-39^{\prime \prime}$ East longitude and $250 \mathrm{mts}$. altitude. The climatic conditions in the Tahsil are strongly influenced by its geographical and topographic conditions. The average maximum temperature not goes beyond $32^{\circ} \mathrm{C}$ and minimum temperature $20^{\circ} \mathrm{C}$. The average humidity ranges from 69 to $95 \%$. The average rainfall received was about 3800 mm/annum ${ }^{1}$.

The pioneering work in ethno-botany of Western Ghats needs to be complete to other communities of Western Maharashtra to make a biodiversity register. The present ethno-botanical work has been carried out on limited aspects. It needs to be comprehensive to other social, cultural and agricultural point of view. While considering the tribal population of Maharashtra, there is a more scope to study ethno-botany in all its aspects ${ }^{6}$.

Some workers ${ }^{10}$ reported medicinal uses of 28 plants by tribals and local practitioners of Ratnagiri districts and documented ${ }^{9} 19$ pteridophytic plant species with their ethno-medicinal uses from Ratnagiri District of Maharashtra. They also stated that these plant species have more Ethno-medicinal potential.

\section{Methodology}

Ethno-medico-botanical survey was conducted in different villages of Dapoli Tahsil during 2008 to 2012 repeatedly for the documentation of traditional knowledge of Tribes and villagers. At the same time, firsthand information was gathered from the local practitioners such as Vaidoos and senior villagers. The information on traditional uses of plants was elicited. The local herbalists were taken individually to the sites where they pointed out the plants which they used to cure different skin diseases. The herbalists were then interviewed on the spot by using a questionnaire ${ }^{11}$. At the same time, photography of the plant specimens was done using digital camera and the plant specimens in flowering / fruiting condition were collected alongwith their field notes and other details in order to identify the plant correctly. The 
TABLE-1: Botanical name, followed by Vernacular name, Family, Name of disease and mode of administration

\begin{tabular}{|c|c|c|c|c|c|}
\hline $\begin{array}{l}\mathrm{S} . \\
\mathrm{N} .\end{array}$ & Botanical Name & $\begin{array}{l}\text { Vernacular } \\
\text { Name }\end{array}$ & Family & $\begin{array}{l}\text { Name of } \\
\text { disease }\end{array}$ & $\begin{array}{l}\text { Mode of } \\
\text { administration }\end{array}$ \\
\hline 1. & $\begin{array}{l}\text { Abelmoschus manihot } \\
\text { var. tetraphyllus }\end{array}$ & Ran-bhendi & Malvaceae & Burns & $\begin{array}{l}\text { Root paste is made in coconut } \\
\text { oil and applied externally }\end{array}$ \\
\hline 2. & Acacia catechu & Khair & Mimosaceae & Wounds & $\begin{array}{l}\text { Powder of bark is applied on } \\
\text { wound twice a day. }\end{array}$ \\
\hline 3. & Ageratum conyzoides & Osadi & Asteraceae & $\begin{array}{c}\text { Skin } \\
\text { diseases }\end{array}$ & $\begin{array}{l}\text { The fresh leaves extract is } \\
\text { applied on infected skin. }\end{array}$ \\
\hline 4. & Alstonia scholaris & Satvin & Apocynaceae & $\begin{array}{c}\text { Skin } \\
\text { diseases }\end{array}$ & $\begin{array}{l}1 / 2 \text { teaspoons stem bark powder } \\
\text { with water is applied externally } \\
\text { till cure }\end{array}$ \\
\hline 5. & Ampelocissus latifolia & Nadena & Vitaceae & Wounds & $\begin{array}{l}\text { The paste of the root bark is } \\
\text { applied on wound }\end{array}$ \\
\hline 6. & Anisomeles indica & - & Lamiaceae & $\begin{array}{c}\text { Skin } \\
\text { diseases }\end{array}$ & $\begin{array}{l}\text { Fresh leaf extract is applied in } \\
\text { infected skin. }\end{array}$ \\
\hline 7. & Argemone mexicana & Pivla Dhotra & Papaveraceae & Scabies & $\begin{array}{l}\text { The latex oozing from the } \\
\text { broken branch is applied on the } \\
\text { infected part at night. }\end{array}$ \\
\hline 8. & Argyreia sericea & Gavel & Convolvulaceae & Wounds & $\begin{array}{l}\text { Cut the fresh stem and applied } \\
\text { on the cut to stop bleeding. }\end{array}$ \\
\hline 9. & Artocarpus heterophyllus & Phanas & Moraceae & Skin diseases & $\begin{array}{l}\text { Leaf extract applied on infected } \\
\text { skin disorders }\end{array}$ \\
\hline 10. & Blumea fistulosa & Bhamburda, & Asteraceae & Wounds & $\begin{array}{l}\text { Leaf juice is applied on cut } \\
\text { portion for early cure. }\end{array}$ \\
\hline 11. & Bolbitis prolifera & $\begin{array}{c}\text { Bhairii } \\
\text { warun vel }\end{array}$ & Lomariopsidaceae & Wounds & $\begin{array}{l}\text { The paste of rhizome is } \\
\text { applied. }\end{array}$ \\
\hline 12. & Calophyllum inophyllum & Undi & Clusiaceae & $\begin{array}{c}\text { Skin } \\
\text { diseases }\end{array}$ & $\begin{array}{l}\text { Oil is applied directly on } \\
\text { wound. }\end{array}$ \\
\hline 13. & Calycopteris floribunda & $\begin{array}{l}\text { Ukshi, } \\
\text { Baganvel }\end{array}$ & Combretaceae & $\begin{array}{c}\text { Skin } \\
\text { diseases }\end{array}$ & $\begin{array}{l}\text { Leaf paste is applied externally } \\
\text { at evening. }\end{array}$ \\
\hline 14. & Careya arborea & Kumbhi & Lecythidaceae & Wounds & $\begin{array}{l}\text { Paste prepared using bark of } \\
\text { 'Kumbhi' stem and 'Ain' stem } \\
\text { applied on cuts to stop bleeding. }\end{array}$ \\
\hline
\end{tabular}




\begin{tabular}{|c|c|c|c|c|c|}
\hline 15. & Casearia tomentosa & - & Flacourtiaceae & Ring worm & $\begin{array}{l}\text { Fresh leaves paste isapplied on } \\
\text { infected part } 2 \text { times in a day. }\end{array}$ \\
\hline 16. & Cryptolepis buchanani & Setakavali & Periplocaceae & Wounds & $\begin{array}{l}\text { The comous outgrowth of the } \\
\text { seed is applied }\end{array}$ \\
\hline 17. & Cullen corylifolia & Bavch & Fabaceae & $\begin{array}{c}\text { Skin } \\
\text { diseases }\end{array}$ & $\begin{array}{l}\text { The leaf paste is applied on } \\
\text { infected parts }\end{array}$ \\
\hline 18. & Datura inoxia & $\begin{array}{l}\text { Dhotra, } \\
\text { Dhothri }\end{array}$ & Solanaceae & Scabies & $\begin{array}{l}\text { Apply fruit powder on infected } \\
\text { skin }\end{array}$ \\
\hline 19. & Desmodium triflorum & Ran-methi & Fabaceae & Wounds & $\begin{array}{l}\text { The juice of leaves isapplied on } \\
\text { cut and wound }\end{array}$ \\
\hline 20. & Entada rheedei & $\begin{array}{l}\text { Garambi, } \\
\text { Gaidhad }\end{array}$ & Mimosaceae & Wounds & $\begin{array}{l}\text { Paste of leaves is directly } \\
\text { applied on wound as an } \\
\text { Antiseptic. }\end{array}$ \\
\hline 21. & Eranthemum roseum & Dasamuli & Acanthaceae & Wounds & Root paste applied. \\
\hline 22 & Euphorbia antiquorum & Nivdung & Euphorbiaceae & Burning & $\begin{array}{l}\text { Apply the latex of stem on } \\
\text { burning skin } 2 \text { times a day. }\end{array}$ \\
\hline 23. & Garuga pinnata & Kakad & Burseraceae & Wounds & $\begin{array}{l}\text { The paste of stem bark is } \\
\text { applied on the injury }\end{array}$ \\
\hline 24. & Girardinia diversifolia & Kolith & Urticaceae & $\begin{array}{l}\text { Scabies } \\
\text { and skin } \\
\text { diseases }\end{array}$ & $\begin{array}{l}\text { Root juice of Kolith and juice of } \\
\text { leaf of Oscimum sanctum is } \\
\text { applied externally for } 4 \text { days. }\end{array}$ \\
\hline 25. & Holigarna arnottiana. & Bibba & Anacardiaceae & $\begin{array}{l}\text { Spots on } \\
\text { skin }\end{array}$ & $\begin{array}{l}\text { Stem bark extract is applied on } \\
\text { infected skin }\end{array}$ \\
\hline 26. & Holigarna grahamii. & Hulgeri & Anacardiaceae & $\begin{array}{l}\text { Spots on } \\
\text { skin }\end{array}$ & $\begin{array}{l}\text { Stem bark extract is applied on } \\
\text { infected skin. }\end{array}$ \\
\hline 27. & Holoptelea integrifolia & $\begin{array}{l}\text { Papda, } \\
\text { Wavli }\end{array}$ & Ulmaceae & Wounds & $\begin{array}{l}\text { Juice of leaf is appliedexternally } \\
\text { only once. }\end{array}$ \\
\hline 28. & Hoya wightii & Dudh-yel & Asclepiadaceae & Burns & $\begin{array}{l}\text { Paste made from leaves is } \\
\text { applied. }\end{array}$ \\
\hline 29. & Hydnocarpus pentandra & $\begin{array}{l}\text { Kadu- } \\
\text { Kavath }\end{array}$ & Flacourtiaceae & $\begin{array}{c}\text { Skin } \\
\text { disease }\end{array}$ & $\begin{array}{l}\text { Seeds crushed are applied } \\
\text { externally }\end{array}$ \\
\hline 30. & Hygrophila schulli & $\begin{array}{l}\text { Kolsund, } \\
\text { Kolshind }\end{array}$ & Acanthaceae & Scabies & Leaves paste is applied on skin. \\
\hline
\end{tabular}




\begin{tabular}{|c|c|c|c|c|c|}
\hline 31. & Hyptis suaveolens & Ran tulas & Lamiaceae & $\begin{array}{c}\text { Skin } \\
\text { diseases }\end{array}$ & $\begin{array}{l}\text { Fresh leaves paste is applied or } \\
\text { the infected skin for } 8 \text { days. }\end{array}$ \\
\hline 32. & Impatiens balsamina & Terda & Balsaminaceae & Burns & $\begin{array}{l}\text { Fresh leaves juice is applied on } \\
\text { burned skin }\end{array}$ \\
\hline 33. & Jatropha curcas & $\begin{array}{l}\text { Mogali } \\
\text { yerand }\end{array}$ & Euphorbiaceae & Wounds & $\begin{array}{l}\text { Latex is applied externally only } \\
\text { once }\end{array}$ \\
\hline 34. & Kalanchoe pinnata & $\begin{array}{l}\text { Panphuti, } \\
\text { Panphui }\end{array}$ & Crassulaceae & $\begin{array}{l}\text { Scabies } \\
\text { and } \\
\text { Wounds }\end{array}$ & $\begin{array}{l}\text { Fresh leaves warmed with } \\
\text { edible oil are applied on injected } \\
\text { part and bind with cotton cloth. }\end{array}$ \\
\hline 35. & Lagerstroemia reginae & Bondara & Lythraceae & Wounds & $\begin{array}{l}2 \mathrm{gm} \text { stem bark paste }+2 \mathrm{ml} \\
\text { Sesamum oil are appliedon cut } \\
\text { as an antiseptic }\end{array}$ \\
\hline 36. & $\begin{array}{l}\text { Lantana camara } \\
\text { var. aculeata }\end{array}$ & $\begin{array}{l}\text { Ghaneri, } \\
\text { Tantani }\end{array}$ & Verbenaceae & Wounds & $\begin{array}{l}\text { Juice of leaf is applied on cut or } \\
\text { wound as anantiseptic }\end{array}$ \\
\hline 37. & Mackenziea integrifolia & Waiti & Acanthaceae & $\begin{array}{c}\text { Skin } \\
\text { diseases }\end{array}$ & $\begin{array}{l}\text { Leaves juice is applied on } \\
\text { infected skin. }\end{array}$ \\
\hline 38. & Meyna laxiflora Robyns & Alu & Rubiaceae & Wounds & $\begin{array}{l}\text { Leaves paste is applied on the } \\
\text { infected part. }\end{array}$ \\
\hline 39. & Mucuna pruriens & $\begin{array}{l}\text { Khaj- } \\
\text { Khujalee }\end{array}$ & Fabaceae & $\begin{array}{l}\text { Sogginess } \\
\text { between } \\
\text { toes }\end{array}$ & $\begin{array}{l}\text { The extract of leaves is applied } \\
\text { to infected partafter washing } \\
\text { at bed time daily till cure. }\end{array}$ \\
\hline 40. & Mussaenda belilla & - & Rubiaceae & $\begin{array}{l}\text { White } \\
\text { spots on } \\
\text { the skin }\end{array}$ & $\begin{array}{l}\text { Fresh root extract is applied on } \\
\text { the infected skin. }\end{array}$ \\
\hline 41. & Ocimum tenuiflorum & Tulus & Lamiaceae & Wounds & $\begin{array}{l}\text { Leaf Paste is appliedexternally } \\
\text { as an antiseptic. }\end{array}$ \\
\hline 42. & Oroxylum indicum & Tetu & Bignoniaceae & Wounds & Paste of stem bark is applied. \\
\hline 43. & Pandanus odoratissimus & Kevda & Pandanaceae & Scabies & $\begin{array}{l}\text { Paste of roots and leaves are } \\
\text { applied on the skin. }\end{array}$ \\
\hline 44. & Passiflora foetida & $\begin{array}{l}\text { Ran Krushna- } \\
\text { kamal }\end{array}$ & Passifloraceae & Wounds & $\begin{array}{l}\text { leaf juice is applied on cut and } \\
\text { wound. }\end{array}$ \\
\hline 45. & Pavetta crassicaulis & $\begin{array}{l}\text { Tudtudi, } \\
\text { Papat }\end{array}$ & Rubiaceae & $\begin{array}{l}\text { Sogginess } \\
\text { between } \\
\text { toes }\end{array}$ & $\begin{array}{l}\text { After cleaning the feet leaves } \\
\text { extract is applied during } \\
\text { sleeping. }\end{array}$ \\
\hline
\end{tabular}




\begin{tabular}{|c|c|c|c|c|c|}
\hline 46. & Plumbago zeylanica & Chitrak & Plumbaginaceae & $\begin{array}{c}\text { Skin } \\
\text { diseases }\end{array}$ & $\begin{array}{l}\text { Fresh root paste is applied on } \\
\text { infected skin. }\end{array}$ \\
\hline 47. & Plumeria rubra & $\begin{array}{l}\text { Pandhara } \\
\text { chapha }\end{array}$ & Apocynaceae & Wounds & $\begin{array}{l}\text { The latex is directly applied on } \\
\text { wound till cure. }\end{array}$ \\
\hline 48. & Pongamia pinnata & Karanj & Fabaceae & Scabies & $\begin{array}{l}\text { The seed oil is applied on the } \\
\text { infected parts of the body during } \\
\text { evening for } 7 \text { days. }\end{array}$ \\
\hline 49. & Pothos scandens & - & Araceae & Wounds & Leaves paste is applied on cut. \\
\hline 50. & $\begin{array}{l}\text { Pterocarpus marsupium } \\
\text { Var. Marsupium }\end{array}$ & Bivla & Fabaceae & Wounds & $\begin{array}{l}\text { Juice of leaf and bark is applied } \\
\text { on cut for to stop blood flow } \\
\text { immediately }\end{array}$ \\
\hline 51. & Securinega leucopyrus & $\begin{array}{l}\text { Pandhar } \\
\text { Phali }\end{array}$ & Euphorbiaceae & Burns & $\begin{array}{l}\text { Dried bark is burned and paste } \\
\text { of ash with coconut oil is } \\
\text { applied on burned skin. }\end{array}$ \\
\hline 52. & $\begin{array}{l}\text { Semecarpus anacardium } \\
\text { Var. anacardium }\end{array}$ & Bibba & Anacardiaceae & Wounds & $\begin{array}{l}\text { Warm seed oil is applied on } \\
\text { cuts and wounds as an } \\
\text { antiseptic. }\end{array}$ \\
\hline 53. & Sida cordata & - & Malvaceae & Wound & $\begin{array}{l}\text { Leaves paste is applied on the } \\
\text { wounds }\end{array}$ \\
\hline 54. & Smilax ovalifolia & Ghotvel & Smilacaceae & Wounds & $\begin{array}{l}\text { The paste of leaf is applied } \\
\text { externally till cure. }\end{array}$ \\
\hline 55. & $\begin{array}{l}\text { Sopubia delphinifolia } \\
\text { Var. delphinifolia }\end{array}$ & Dudhali & Scrophulariaceae & Wounds & $\begin{array}{l}\text { Fresh leaf extract is applied on } \\
\text { cuts. }\end{array}$ \\
\hline 56. & $\begin{array}{l}\text { Stereospermum } \\
\text { chelenoides }\end{array}$ & Padal & Bignoniaceae & Wounds & $\begin{array}{l}\text { The fresh leaf paste is applied } \\
\text { on the cut. }\end{array}$ \\
\hline 57. & Tamarindus indica & Chinch & Caesalpiniaceae & Burns & $\begin{array}{l}\text { Ash of leaves with coconut oil is } \\
\text { applied on burned skin. }\end{array}$ \\
\hline 58. & Terminalia cuneata & $\begin{array}{l}\text { Arjun } \\
\text { sadada }\end{array}$ & Combretaceae & $\begin{array}{l}\text { Burns } \\
\text { and wound }\end{array}$ & $\begin{array}{l}\text { Ash of leaves with coconut oil is } \\
\text { applied on burned skin. }\end{array}$ \\
\hline 59. & Terminalia elliptica & Ain & Combretaceae & Wounds & $\begin{array}{l}\text { Paste of bark is applied } \\
\text { externally on the cut, it act as } \\
\text { anticoagulant \& antiseptic. }\end{array}$ \\
\hline 60. & Terminalia paniculata & Kinjal & Combretaceae & Wounds & $\begin{array}{l}\text { The paste of bark or leaf is } \\
\text { applied till cure }\end{array}$ \\
\hline
\end{tabular}




\begin{tabular}{l|l|l|l|l|l}
\hline 61. & Tinospora cordifolia & Gulvel & Minispermaceae & Wound & $\begin{array}{l}\text { Stem juice is applied on } \\
\text { wounds. }\end{array}$ \\
\hline 62. & $\begin{array}{l}\text { Trichosanthes } \\
\text { tricuspiculata }\end{array}$ & Kaundal & Cucurbitaceae & $\begin{array}{l}\text { Wounds } \\
\text { and burns }\end{array}$ & $\begin{array}{l}\text { The stem paste is directly } \\
\text { applied on wounds and burns as } \\
\text { an antiseptic. }\end{array}$ \\
\hline 63. & Tridax procumbens & Yekdandi & Asteraceae & Wounds & $\begin{array}{l}\text { Leaf juice is directly applied } \\
\text { once a day till cure }\end{array}$ \\
\hline 64. & Woodfordia fruticosa & Dhayati & Lythraceae & Wounds \\
and Burns & $\begin{array}{l}\text { Burning: Paste made with ash } \\
\text { of leaves andflowers and } \\
\text { Coconut oil is applied on burned } \\
\text { skin. Wound: Leaves tied on } \\
\text { the wounds. }\end{array}$ \\
\hline
\end{tabular}

information obtained was crosschecked from other herbalists. The collected plants specimens were identified with the help of available literature ${ }^{3-5,7,8,12-14}$. The collected plant specimens were preserved ${ }^{6}$. The preserved plant specimens were compared with standard herbarium of BSI, Western circle, Pune.

The field data have been collected on plant parts used in preparation of drugs, local name, its dosage and administration (Table-1). The information on medicinal uses of plants has been recorded on the basis of knowledge of 3 Herbalists and observations from different localities and had similar comments about the medicinal use.

\section{Observations}

The reported ethno-medicinal plants used by Tribals and Villagers are arranged in alphabetical order of Botanical name, followed by Vernacular name, Family, Name of disease, and mode of administration (Table.1)

\section{Result and Discussion}

Total 65 plant species belonging to 62 genera of
39 families are used in different forms to control the skin diseases, burns, cuts and wounds by villagers and tribal people from study area. Out of total 65 species, 1 species belongs to Pteridophytes, 64 species belong to 61 genera of 38 different families of Angiosperms. Out of 64 species of Angiosperms, 62 species belong to 59 genera of 36 families of Dicotyledons while 2 species belong to 2 genera of 2 families of Monocotyledons. Fabaceae is the dominant family with 5 species used followed by Combretaceae with 4 species and Lamiaceae, Asteraceae, Apocynaceae, Acanthaceae families with 3 species each are reported. It is also observed that, 33 plant species leaves, followed by 16 plant species stem or stem bark followed by 7 plant species roots and 4 plant species seeds are used to control of skin problems.

Rural and aboriginal population is using various plants as a source of medicine as they are far away from medical facilities ${ }^{2}$. But it is found that, the people not only from rural area but also from urban area are using the herbs for effective and complete control of skin diseases without side effects.

\section{References}

1. Anonymous. Progress Report of Agro metrological Scheme, Department of Agronomy, Dr. B. S. Konkan Krishi Vidyapeeth, Dapoli, Dist. Ratnagiri (M.S.). 2008-2012.

2. Apate SA. Studies on less known uses of some medicinal plants from Sindhudurg District of Maharashtra State. Ethnobotany. 2016; 28: 91-94

3. Captain Beddome RH. The ferns of Southern Indian, Being descriptions and plates of the ferns of the Madras Presidency. Today and Tomarrow's Printers and Publishers, New Delhi-5. 1970. 
4. Cook T. The flora of the Presidency of Bombay. (Reprint 1958) Botanical surey of India, Hawarh, I-III. 1901-1908.

5. Dixena D, Patel DK. Plants as a source of medicine among the tribes residing in Kota block of Bilaspur district (C.G.) India. Flora and Fauna. 2019; 25 (2) : 195-203.

6. Jain SK, Rao RR. A Handbook of Field and Herbarium Methods. Today and Tomorrow's Printers and Publishers, New Delhi. 1977; 22-72.

7. Kulkarni DK, Kumbhojkar MS. Status and prospects of Ethnobotany in Western Ghats of Maharashtra. Ethnobotany. 2002 ; 98-118.

8. Manickam VS, Irudayaraj. Pterid. FI. West. Ghats- S. India. 1992.

9. Masal VP, Dongare MM. Studies on Ethno-medicinal uses of Pteridophytes of Ratnagiri District (Maharashtra, India). Indian Fern J. 2010; 27 : 88-93.

10. Mokat DN, Deokule SS. Ethno-medico-Botanical survey of Ratnagiri District of Maharashtra State. J. Econ. Taxon. Bot. 2004; 28 (3): 19-23.

11. Mokat DN. Ethno-medico-botanical studies on Thane and Ratnagiri districts with respect to indigenous knowledge with an aid of Pharmacognosy. Ph.D. Thesis submitted to University of Pune, Pune. 2005.

12. Sharma BD, Karthikeyan S, Singh NP. Flora of Maharashtra state Monocotyledons. BSI. Calcutta. 1996.

13. Singh NP, Karthikeyan S. Flora of Maharashrta state Dicotyledones, BSI, Calcutta, I. 2000.

14. Singh P, Lakshinarasimshan P, Karthikeyan S, Prasanna. Flora of Maharashtra state Dicotyledones, BSI, Calcutta, II. 2001 